Canadian University Music Review

Canadian University Music Review

Revue de musique des universités canadiennes

William Ashbrook and Harold Powers. Puccini's 'Turandot':

The End of the Great Tradition. Princeton Studies in Opera.

Princeton: Princeton University Press, 1991. x, 193 pp. ISBN

0-691-09137-4 (cloth), 0-691-02712-9 (paper)

\title{
Patricia Debly
}

Numéro 13, 1993

URI : https://id.erudit.org/iderudit/1014306ar

DOI : https://doi.org/10.7202/1014306ar

Aller au sommaire du numéro

Éditeur(s)

Canadian University Music Society / Société de musique des universités

canadiennes

ISSN

0710-0353 (imprimé)

2291-2436 (numérique)

Découvrir la revue

Citer ce compte rendu

Debly, P. (1993). Compte rendu de [William Ashbrook and Harold Powers. Puccini's 'Turandot': The End of the Great Tradition. Princeton Studies in Opera. Princeton: Princeton University Press, 1991. x, 193 pp. ISBN 0-691-09137-4 (cloth), 0-691-02712-9 (paper)]. Canadian University Music Review / Revue de musique des universités canadiennes, (13), 165-168.

https://doi.org/10.7202/1014306ar

All Rights Reserved (C Canadian University Music Society / Société de musique des universités canadiennes, 1993
Ce document est protégé par la loi sur le droit d'auteur. L'utilisation des services d'Érudit (y compris la reproduction) est assujettie à sa politique d'utilisation que vous pouvez consulter en ligne.

https://apropos.erudit.org/fr/usagers/politique-dutilisation/ 
wealth of information, the illustrations and drawing, it might just be possible for a skilled craftsman to make such an instrument. However, having watched the author in his workshop, I would advise caution. It is not quite so easy as it reads.

Robert Barclay's text is lively and always interesting. What might have become a rather dull statement of facts, and possible academic, is a very readable book; I would recommend it to all who have more than a passing interest in the early trumpet.

Robert Oades

William Ashbrook and Harold Powers. Puccini's 'Turandot': The End of the Great Tradition. Princeton Studies in Opera. Princeton: Princeton University Press, 1991. x, 193 pp. ISBN 0-691-09137-4 (cloth), 0-691-02712-9 (paper).

For more than a decade scholars, students, and connoisseurs of opera have been able to consult two series of books on opera: the Opera Guides in association with the English National Opera and Royal Opera (Calder Publishers) and the Cambridge Opera Handbooks (Cambridge University Press). To date, both series have focused on the major works in the repertoire, devoting an entire volume to one opera, with discographies and bibliographies for further study. Here the similarities end. The English National Opera Guides are written with the intention of enlightening the general opera-going public, giving them a series of introductory essays which focus on a specific opera in its historical context, the libretto as literature, and the important aspects of the musical style. The second half of the book contains the libretto in its original language accompanied by an English translation. The Cambridge Opera Handbooks differ not so much in the types of issues addressed as in the manner of discussion. These volumes are definitely written for the musically literate since they contain more musical analysis and thoroughly examine some pertinent issues of the particular opera. According to the "General Preface," each handbook has three main areas: history, analysis, and the influence of critical writing on the appreciation of structural elements. The historical discussions focus on the genesis of the libretto and the music and give a performance history. The detailed musical analysis considers musical and dramatic effects within the context of the overall structure.

Princeton Studies in Opera is a new series on opera scholarship, introduced in 1991 by Princeton University Press. Puccini's 'Turandot' is the first book in the series, followed by Unsung Voices: Opera and Musical Narrative in the Nineteenth Century (1991) by Carolyn Abbate. From these first two publications it appears that this series is proceeding in a different direction from previous ones, appealing directly to opera scholars who are well acquainted with the 
repertoire. Ashbrook and Powers have placed the opera Turandot within the tradition of nineteenth-century Italian melodramma and the works of Rossini, Bellini, Donizetti, and Verdi. The authors conclude their Introduction with the book's raison d'être:

Our concern is not with Turandot as one among a number of socio-historical reflections of a phase or an aspect of Western culture, but simply as a work worthy of consideration in its own terms, as the last Monument in the last Golden Century of one of the world's Great Traditions of musical theater (p. 11).

Perhaps it is not just a coincidence that Turandot has a complete volume devoted to it. The previous literature on this opera is for the most part superficial anecdotal with lengthy plot synopses and subjective and descriptive musical analysis. ${ }^{1}$ I believe that Turandot warrants serious study since this opera presents so many interesting issues in terms of harmonic and tonal language and colour, to say nothing about the fact that Puccini had completed only sketches for the final scenes of the last act before he died. ${ }^{2}$ Perhaps the greatest enigma of this opera is not the three riddles posed by the Princess Turandot to the unknown Prince Calàf, but the question of what Puccini would eventually have composed as its ending. Ashbrook and Powers' book, Puccini's 'Turandot' considers these matters in a more thorough and substantial manner than previous writers have done.

To facilitate the subsequent discussions of Turandot, the first chapter is devoted to explaining how the authors have subdivided the work into a number opera via major musico-dramatic sections (using upper-case letters) with further division into individual "movements," such as arias and choruses (using Arabic numerals). Rehearsal and measure numbers from Ricordi's published scores are quoted to give the exact location for the beginning of each subsection. The rest of the chapter involves systematically progressing from one subsection to the next, listing the main characters with a brief description of their actions, the incipit of the numbers, the musical motives (with musical examples), and the tempo marking, meter, and tonality. Any noteworthy musical characteristics, such as bicentric harmonies, sequences, or modulations are mentioned.

1 Some of the exceptions include Mosco Carner's Puccini: A Critical Biography (London: Duckworth, 1974) and Turandot (Nicholas John, ed., English National Opera Guide, No. 27; London: John Calder Publishers, Ltd., 1984). The Operas of Puccini by William Ashbrook (Oxford: Oxford University Press, 1985) is informative only from a literary viewpoint.

2 Puccini died on 29 November 1924, leaving Turandot unfinished. He had completed the orchestration of Act III up to the end of Liù's cortege. 
The remainder of the book is devoted to the history of Turandot as an opera (Ashbrook) and to two chapters of musical analysis (Powers). Chapter 3, "The Genesis," collaboratively written, is an important chapter because it reveals Puccini's compositional process and how intimately he worked with his librettists, Adami and Simoni, and demonstrates how Puccini perceived the importance of the text. With ample documentation from Puccini's letters to his librettists, Ashbrook and Powers follow chronologically the process of changes and revisions to the libretto within the context of the dramaturgy of the opera and its characters. This lucid and meticulous account is enhanced by the chart (p. 67) which compares the 1921 long Act I libretto with the final 1924 version (now divided into two acts).

Ashbrook's two chapters examine Turandot from a historical and literary standpoint. In chapter 2, "The Sources," Ashbrook outlines in a clear and succinct manner the various correspondences and differences between the original play by Carlo Gozzi (1761) and that of Schiller's German adaptation, Andrea Maffei's Italian translation of Schiller, and Puccini's libretto. The historical approach continues with a brief survey of German composers who wrote various operatic adaptations of Turandot. Special consideration is given to Bazzini's and Busoni's Turandot operas, within the context of Puccini's work.

"Turandot Staged" is the last chapter in the book. Ashbrook's painstaking research into production details and newspaper reviews is presented in an engaging manner. Beginning with Puccini's own involvement in the scenery, and costumes for the first performance, Ashbrook leads the reader systematically through Giovacchino Forzano's production book. After debating the validity of the music critics' reviews in the press (since Toscanini had conducted the opera only up to where Puccini had left off [Liù's cortege]), Ashbrook briefly discusses subsequent international performances.

Puccini's score is a merging of many diverse elements of musical styles. Mosco Carner divided the opera into four categories: the lyric-sentimental (Liù), the heroic-grandiose (Calàf and Turandot), the comic-grotesque (the Masks), and the exotic. ${ }^{3}$ On the other hand, Powers in his analysis of the music has divided his chapter into four "colors": Chinoiserie (both authentic and invented), dissonances and half-steps, Persian Prince and Chinese slave (the funeral music for both), and the Puccinian norm ("Romantic-diatonic"). He explains his reasoning for these classifications:

In Turandot it is general colorings, rather more than motivic labels, that are associated with characters and situations; the opera is full of various kinds 
of that generalized couleur locale that Verdi scholars today sometimes call tinta musicale or colorito,... In Turandot, far more than in any of Puccini's other operas, tinta is structural: it emerges from a web of interlocking resemblances and contrasts based on tempo or pacing, on instrumental and/ or harmonic color, on melodic or rhythmic topoi and types, on the texture of accompaniment patterns, and so on (pp. 93-94).

Powers explores each tinta separately, discussing it in terms of how it functions musically within the dramaturgy of the whole opera, in the context of both smallscale and large-scale melodic, harmonic, and tonal relationships.

In contrast to this, his second chapter of musical analysis concentrates on the two duets involving Turandot and the Prince. The first duet is the Enigma scene in Act II, when Turandot poses her three riddles, which depending on the unknown Prince's responses, will result in either his death or her hand in marriage. Powers analyses the duet from a number of different vantage-points: the unifying elements of tonal closure and the choral Acclamation; the use of the Mo-li-hua theme to link the duet to the rest of the opera; and how the employment of the same theme for Turandot's questions and the Prince's responses strengthens the drama rather than weakens it (in contrast to previous authors who have puzzled over Puccini's reasoning). The second half of the chapter is devoted to the problem of the opera's unfinished state at the time of Puccini's death. Powers carefully documents Puccini's drafts and sketches and discusses his probable intentions for the final score with reference to Franco Alfano's two settings for the conclusion of Act III. ${ }^{4}$

Overall, the writing style is clear and concise, and the two authors' contributions complement one another. What is unusual is the use of atypical metaphors for commonly held ideas about opera. For example, the authors use chemistry to explain the importance of the combination of music, text, scenery and action in an opera: "Opera is a compound, not an amalgam. ... Subatomic features in the several elements are electrically bonded in the chemistry of the genre" (p. 12).

Puccini's 'Turandot' is a welcome addition to Puccini scholarship, helping finally to sweep under the carpet the remnants of incorrect, subjective, and unintelligible criticism from earlier in this century. Ashbrook and Powers have laid to rest the notion that Puccini's Turandot is unworthy of serious study.

Patricia Debly

4 For a comparison of ideas on this subject the reader should consult Jürgen Maehder's article (to which Powers makes reference), "Puccini's Turandot: A Fragment" (Nicholas John, ed., Turandot, 35-53), and a more recent article by Janet Maguire, "Puccini's Version of the Duet and Final Scene of Turandot" (Musical Quarterly 74, no. 3 [1990]: 319-59), which explains and justifies her new version of the duet and final scene based on Puccini's sketches and the original text with references to earlier passages in the opera. 